\title{
The Interstitial Language and Transnational Experience
}

\section{PAOLO BARTOLONI}

NATIONAL UNIVERSITY OF IRELAND, GALWAY

\section{-INTRODUCTION}

It is not uncommon that migrant communities as well as local governments celebrate cultures, traditions and customs by erecting monuments, dedicating streets and squares to them and even replicating symbols of community bonding and sociability. This is, for instance, the case of the Italian Forum, an alleged replica of an Italian square in the heart of Sydney's 'Little Italy' in the suburb of Leichhardt. Such projects originate from a genuine belief in the need to pay witness to the contribution of migrants, to their identity and to the ways in which this identity has come to interact and be shared with the host culture. Monuments, squares and streets acquire, in this context, meanings that connect and link diversity by reframing it within a dialogue, which is both assertive of specificities typical of a given identity but also inclusive and porous to other symbols and suggestions. As a result, these sites speak a complex language that is simultaneously original and translated, in-place and out-of-place, and in the present as well as in the past through recollection and memory. They speak, therefore, by virtue of a symbolic 
expression that is not so much embedded in ideas of purity and authenticity as in those of interstitiality and transnationality. The vocabulary and lexicon of this language cannot be approached through the paradigm of national cultures because, as we shall argue in this article, nations are built on symbolism that is more often than not predicated on exclusion. It is in this context that the phenomenological and poststructuralist conceptualisation of experience and knowledge, understood here as the process of cultural production through the employment of meaningful forms, must be reviewed according to new parameters of engagement predicated on cultural encounters and exchange. This is the intent of this article, which, by mobilising both phenomenology and poststructuralism, will first challenge the national bias inherent in their application and second reorient their critical perspectives within a transnational framework.

The Italian Forum is a replica of an Italian square. Off Norton Street, the main thoroughfare of Leichhardt's 'little Italy', it is an integral part of the suburb's life, providing a mixture of commercial premises, private residences and cultural spaces. The semantic field pertaining to the concept of replica is not without analogy to adaptation and translation. We could talk about the Italian Forum as a translation or adaptation of the original meanings and atmosphere of the idea of squares in Italy. The added problem here is that the translator or adaptor is working not from one language into another language, but across languages. In the case of the Italian Forum, the translator is itself an idea made up of national as well as hyphenated identities, whose relation with the original is both close and removed by time, space and intentions. Moreover, the result of the translation is a physical place that can be experienced as a recollection of identity, an emblem of national pride, an encounter with the Other, a re-enactment of a foreign experience and an exciting discovery of the Other in oneself. The Italian Forum is an interesting mirror that can be used to search in the past for a lost origin or in the present to recognise the typical trait of duality and hybridity. Sigmund Freud's theory of the uncanny is particularly appropriate as a device to open up issues of translation, adaptation, and reification in which difference and unfamiliarity - the foreign echoes resonating in languageare nothing other than our own face under a different light or slightly distorted, precisely as in a mirror. 
The Italian Forum is an enclosed space, more akin to an amphitheatre than a square. A long and narrow passage, flanked by shops and restaurants, leads from the main road, Norton Street, to the centre of the Italian Forum. The first thing impressed upon the eye as one arrives in the Italian Forum is the terracotta and yellow colours of the buildings. These rise as if from a central courtyard to form a quadrilateral divided into three layers. Shops, restaurants and cafes occupy the ground floor and first level, while the other levels are dedicated to residential units and flats. Private balconies and windows open on to the public space beneath, enacting exchange and constant dialogue between the public and the private. The central side of the Forum is dominated by a terracotta building with a large clock on the façade, halfway between a municipal building and a church. To the left of this building, on the ground floor, there is a fountain in the middle of which stands a statue of Dante on a pedestal. On either sides of the courtyard, facing each other, are a cultural centre and a library. The ground floor or the central courtyard of the Forum is accessible through a central set of concrete stairs at the end of the main corridor from Norton Street and through side stairwells opening at intervals on the first floor. There are also lifts connecting the various floors. Archways and porticos frame the courtyard, constituting an undercover corridor interspersed with shops, cafes and restaurants, whose tables and chairs spill out on to the open square.

A few years ago, in an earlier essay on the Italian Forum, I argued that the piazza in Leichhardt was a 'bad translation' of an Italian square. ${ }^{1}$ My intention was not derogatory; it was instead aimed at bringing to the fore of critical discourse the quintessential openness of translation, whose primary function is that of reminding its audience that the original is somewhere else. The logical conclusion of that preliminary interrogation of the Italian Forum invites me to argue today that, paradoxically, 'good translations' must be incomplete, clearly different-not so much to state their individual agency (which however they have the right to do) as to keep the creative process of exchange and encounter ongoing. The Italian Forum in Sydney is a significant example of transnational language precisely because its language and symbolism are ostensibly interstitial, in-between, resisting established values and tastes readily connected with a nation state. There is much about Italian culture in the Italian Forum, but there is also much about Australian culture. Yet more importantly, it presents a moment and a place where Italy and Australia meet 
as a result of a process of mutual mediation where the 'I' is also the 'other', and where the uncanny is located not so much in the feeling of estrangement and displacement as in the curious and rather exciting feeling of being at home outside home. The cafes and the restaurants in the square have similar menus to those one can find in Italy; one can have an ice cream and stroll around under the portico window-shopping while listening to and observing the passers-by. The atmosphere is almost right. There remains, though, an excess which rings persistently in the ears; the light is different, the statue of Dante is the wrong proportion, and the people move with a sort of self-conscious mannerism as though they were part of a performance, acting both the part of themselves and that of the other. Welcome to the transnational place.

But let us proceed step by step, starting with the phenomenological experience, and the significance that place and context acquire in the philosophical project of Martin Heidegger. Heidegger returns to the notion of 'inhabiting' and 'dwelling' with a continuity that is neither coincidental nor accidental. Moreover, he does so at crucial moments of philosophical conceptualisation, the same ones that underpin his idea of Dasein; that is, Heidegger's peculiar understanding of individuality and being. In 'Letter to Humanism' Heidegger states, for example, that language is the house of being and, analogously, that being is the house of language. ${ }^{2}$ In 'Building Dwelling Thinking' he argues that the very meaning of being is to be found in the situatedness on earth, which for him equates with the notion of inhabiting. ${ }^{3}$ According to Heidegger we are humans because we inhabit the earth, and we do so by dwelling in a house that is given by language. At first this may seem to be a rather uncontroversial argument, especially within the framework of an a-priori temporal and spatial paradigm, and of a generic understanding of earth. Indeed, what is it that Heidegger means by earth? He means both soil and world; in other words a combination of local and cultural specificities-what Pierre Bourdieu would call cultural capital. Soil and world are, for Heidegger, inseparable, and together they constitute the meaning and authenticity of Dasein (being). It is in this sense that for Heidegger the notion of earth is far from generic, unless one would attempt to link earth with the idea of a prelapsarian state. Yet there is nothing more alien to Heidegger than the messianic conceptualisation of being proposed, for instance, by Walter Benjamin. 
Benjamin and Heidegger both understood human individuality as that which is marked by the experience of language, but whereas Heidegger focused on specific, given languages, which, in his case, were pre-Socratic Greek and German, Benjamin chose to approach language from the interrogation of the palimpsest, that is 'pure language'. In essays such as 'The Task of the Translator' and 'On Language as Such and on the Language of Man', Benjamin attempted to follow the development of languages starting from a mythical and ideal language-'pure language', the language before the fall. His interest focused not so much on returning to a supposed origin as that of tracing the mysterious and often invisible connections among different languages; those moments of linguistic thresholds, which for him were also the moments of shared humanity. Benjamin located these moments in the interstitial experience par excellence: the process of translation. ${ }^{4}$ For Heidegger, translation was instead a mode of inquiry that would bring him closer and closer to the origin, to the source text, to the pre-Socratic writings, that is, a mode in which he saw the authentic traits of being. ${ }^{5}$ This process would allow him to replicate the experience of pre-Socratic thought through German. ${ }^{6}$ Heidegger recognised in the soil and world of ancient Greece signs of the earth that he considered to be quintessentially human, and attempted to relive them by recuperating and finding them in his writings and the writings of other authors who wrote in German, including Hölderlin, Rilke, George and Trakl. ${ }^{7}$

For Heidegger earth, house, language are, then, strongly connected to a place and a tradition, and to a sense of quasi-deterministic belonging and authenticity. ${ }^{8}$ Let us return, now, to the notion of individuality as that of inhabiting a house made of language. By applying the Heideggerian perspective the house is imposing, extremely sophisticated and beautiful, but also gated, intimidating and excluding. In this essay I argue that the idea of inhabiting, and of human individuality as the house of being, are fruitful ideas if located in a space which is defined by movement, porosity and interstitiality, and in an urban and architectural paradigm which is based on openness and inclusiveness. Transnational experiences and localities can be, to this end, extremely instructive. It is essential to articulate the notion of dwelling within an urban context in which building is the result of complex cultural and social interactions, characterised not only by the negotiation of space and materials but also, and more importantly, by a range of symbolic values. The 
symbolism that I refer to here is the product of mnemonic and emotional experiences marked by time and space, which in the case of the migratory and transnational experiences is arrived at through a delicate negotiation of the past and the present, and the 'here' (the current locality) and the 'there' (the native locality). The dwelling that I speak of is, therefore, a double dwelling divided between the present at-hand and the remembered past, and as such it inhabits a space, which is both interstitial and liminal, simultaneously in-place and out-of-place.

I have chosen the Italian Forum in Sydney as a working sample of the place-outof-place, and as a case study to interrogate the processes of inhabitation that, according to Heidegger, makes us what we are. But contrary to Heidegger, for whom inhabiting is the cipher of authenticity and purity, the concept of being that I would like to provide here is that of the cosmopolitan and transnational dweller who lives in multiple spaces at once, both in reality and imagination, in the present, and in the past through memory. Translation, and in particular Benjamin's understanding of translation as the mediation of languages, adds a significant layer of meaning, as well as critical inquiry, to the category of the transnational insofar as the transnational experience and lexicon are invariably and always translated. It is in this sense that co-participation and the willingness to enable a shared experience are inherently acts of translation conducted on the neutral ground of liminality. The process, and not the final and polished result which is usually characterised by the imperative of domestication, is the quintessential trait of translation and the transnational. I might be considered cynical or naive, yet I maintain that the modest success of the commercial aspect of the Italian Forum is a powerful testimony to the processual nature of its development, over which a sense of incompleteness has persisted.

The first section of this article discusses the city and its spaces as loci of plural encounters and formations, which is at the basis of our understanding of civitas. This is discussed in comparison with and contrast to Heidegger's philosophy of space. The second section looks at the idea of social objects by drawing on the work of Foucault. This discussion is related to Freud's notion of the uncanny and argues that the cohabitation and co-presence of supposedly antonymic concepts such as authentic/inauthentic, in/out, self/other are incredibly fruitful impulses toward human production and creativity. Examples from and references to the Italian 
Forum are interspersed throughout the essay. The essay concludes with an overview of the square in Leichhardt, which, by this stage, will have hopefully revealed a signature that either consciously or unconsciously, by default or will, can be inscribed in the multiple zone of transnational experiences.

\section{-POLIS AND CIVITAS}

The history of urban settlements and their formation is marked by two ideas that are the development of the same desire for socialisation, security, preservation, and community. The Greek polis and the Roman civitas are related, and yet based on diametrically opposed conditions of belonging. They both strive to offer unity and a degree of social togetherness predicated on the process of integration and mutual acceptance; but whereas the polis aims at achieving this through the insistence on an identifiable origin and clear roots (cultural and linguistic), the civitas emphasises the notion of reciprocity, which is not necessarily related and connected to the principle of sameness. In a recent book, Polis in fabula: Metamorfosi della città contemporanea, (Polis in Fabula: The Metamorphosis of the Contemporary City) the Italian scholar Anna Lazzarini ${ }^{9}$ provides a sustained discussion of the conceptual differences between the two concepts of city by drawing on the work of Aristotle and Emile Benveniste, among others. Lazzarini argues that while the two terms have often been employed interchangeably they differ in substance and should not be confused since they propose two rather different understandings of urban dwelling. One, the polis, is the centre of the ethos of an identified genos; the other, the civitas, is the result of a constituted social centre based on fluxes, mobility and encounters determined by expansion, conquest, and trade. While the former rests on the traditions and mores of a particular ethnicity, guarding and preserving them, the latter is porous, open and constantly fluctuating. From this it follows that the origin is an essential ingredient of the polis, for which belonging is based on the recognition and certification of identity. The constitution of the city is in this instance the necessary step towards the safeguarding and the consolidation of a perceived authenticity. Location and place appear to be the central elements of the civitas, which emerges not so much from a given origin as from series of vectors and forces that converge and meet in particularly suitable areas. The city is here the centre that encourages and enables movement in and out of its perimeter. If by 
synecdoche we approximate the idea of the Heideggerian notion of 'inhabiting as the house of being', we could argue that the distinction between polis and civitas generates two rather different 'houses': one is closed, guarding and preserving (polis) the other is open and inclusive (civitas). One, the polis, is based on strong values determined by the authenticity of language and traditions (let us remember that for Heidegger the house is also the house of language), the other, the civitas, is characterised by serendipity and plurality, including the plurality of languages.

The contemporary city is an interesting blend of polis and civitas in which the desire to guard and preserve is constantly checked by the opposite thrust to include and welcome. It is the constant tension between these two forces that characterises the development of the contemporary urban design, and also ignites the imagination and symbolic production of social objects and structures. ${ }^{10}$ Cities such as Melbourne and Sydney provide instructive examples of urban conglomerates that are simultaneously polis and civitas, where centralisation is counterbalanced by a centrifugal force towards the fringes and the periphery. In the cases of Melbourne and Sydney one cannot really speak of a recognisable centre, but rather of multiple centres, whose configuration and forms of aggregation are often determined by class, status and ethnicity. Toorak and Carlton in Melbourne and Vaucluse and Leichhardt in Sydney are clear examples of decentralised centres that were constituted by social status (middle and professional classes) in the first instance and ethnic origin (Italian) in the second instance. Paradoxically, the so-called Australian urban centres were marked by artificially agreed locations (the position of the central post office), and the convergence of business related activities (the famous central business district (CBD). Their very constitution, based around finance and ideal spatial markers, while determining a sort of template in relation to distances and economic power, consigned the Australian urban centres to anonymity. They were busy during the day but virtually deserted at night, and the flurry of activity that characterised them was, to most people, invisible and intangible. The life of the polis was reconstituted away from the CBD in the perceived and often concrete nucleus of the suburb where cultures, traditions and languages occupied the space, ordering interpersonal relations and exchange. As Australian cities became globalised following international trends, the dynamic 
between centre and periphery, CBD and suburbs altered too; the distinction that was described above became less obvious.

The same combination of impulses that define the polis as opposed to civitas are also found in individual urban developments such as at the Italian Forum. Nowhere more than in places that celebrate cultural encounters does the resilience of allegedly cultural, religious and language identity remain and endure. But they do so not so much in defiance as in a performative display of attractiveness. The replica of the Italian Piazza is clearly conceived to lure one in with the promise of authenticity, which is in turn complemented and balanced by concession to local taste and sensitivity. The coffee and the gelato may be authentic, and yet the statue of Dante, so minuscule, is not overpowering. The presence of the Italian poet serves as a symbol of national greatness, but more as an echo and as a footnote in which Dante is subtly incorporated into a vague notion of world and universal literature. Naturally, globalisation brings mobility and a degree of touristic cosmopolitanism, which colour relevant suburbs and places with a patina of fascination. All of a sudden the Other has become trendy, or, rather, the impersonation of some of the assumed characteristics of the Other by remaining ourselves has become trendy and fashionable. In his book Atmosferologia: Estetica degli spazi emozionali (Atmospherology: The Aesthetics of Emotional Spaces), the Italian philosopher Tonino Griffero writes about the mutual influence between objects and individuals, and how particular objects create a particular atmosphere that pulls the individual in. ${ }^{11}$ Griffero goes so far as to argue for a new aesthetics based on atmospheres that characterise choices and behaviour. ${ }^{12}$ In the context of the Italian Forum, one could well speak of the Italian atmosphere conjured therein. The consideration that Italians do not necessarily go to the Italian Forum does not detract from the supposed authenticity of the experience. What makes this square unique and special is its atmosphere, which is both the result and product of history (the history of the Italian settlement in Australia) and globalisation (the opening up of spaces by cultural curiosity and trends).

Polis and civitas are thus combined in the porous and intermingling experience of the contemporary city where movements occur simultaneously inwards and outwards, and where encounters and exchanges are not only based on more or less chance or conscious meetings with the Other but also on the very fashioning of the 
self on the perceived image of the Other. The Italian Forum in Sydney is a clear example of a melange of interests and forces which draw together Italian heritage, tourist cosmopolitanism, the identification with the Other, consumerism and urban planning motivated by an idea in which polis and civitas are blended in a perfect example of contemporary design and thinking. By breaking open and tearing apart the centralisation of business in one identified centre of operation, globalisation has made the idea of the CBD incongruous and null, but it has also transformed the notion of life as revolving around a centre of culture, traditions and language. Life and work, trade and fun are increasingly fused, and the private and public are no longer separate domains but rather an intricate vector of emotions, interests, desires and knowledge, played out on a spatial platform the place of which is multiple, pluricultural, transnational and linguistically mixed. It is significant in this context to remark and stress the successful attempt to bring the private and the public together in the Italian Forum by designing a space that is simultaneously residential and commercial. The apartments that frame the square overlook the activity in the piazza but can also be observed by the people below in a constant exchange of curious glances and invitations. Something similar, although on a much larger scale, has taken place with the transformation of Melbourne's CBD into a successful site of business, art and leisure. This is also the symbolic stamp of a city moving towards a centralised decentralisation, by which I mean the creation of multiple centres ordered by a series of respective atmospheres and their different symbolic importance.

One would be mistaken to think that such urban developments signal an end to the tensions and anxieties revolving around Otherness, and the eclipse of notions such as authenticity and inauthenticity. These conflicts remain, but are pushed further out, to the margin of the city, and become invisible to the majority of the transnational and cosmopolitan curios. These are the poor, disenfranchised, highly ethnic areas the margins of which are geographic, psychological and emotional, and for which no aesthetics, let alone an aesthetic atmosphere, exist. It is in this sense that the transnational space, of which the Italian Forum is an example, symbolises at one and the same time the attempt to capitalise on the fascination of the Other while assimilating her by a process of domestication. This is achieved through a complex and rather subtle manipulation of Otherness and its uncanny presence; the uncanny 
is maintained and preserved yet turned into a performance in which the ' $I$ ' must play an important part: 'I' am the other and assume her trait by projecting myself into a place which is both real and virtual. Reality is provided by history, and the epochal transformation makes history virtual.

What has happened to Heidegger's house, and to his idea of inhabiting as the quintessential trait of humanity? The concept of inhabiting is very pertinent and still current, as is that of the house as a metaphor for the necessity of place. What is at stake here, though, is the confrontation of two very distinct notions of house; one is based on a strong sense of belonging and tradition (Heidegger), while the framework of the other is instead offered by a sense of belonging which paradoxically appears to defy the very notion of belonging. In other words, it is an identity that is based on a virtual belonging, which is at the same time authentic and inauthentic, same and other, in and out. Both identities are still relevant, and still drive political as well as economic discourses, in the context of which the struggle to arrive at a united and integrated Europe made of different states (houses) is an interesting case. Here, I am not so much interested in providing a close analysis of these two tendencies as in investigating the creative and aesthetic processes that underpin the elaboration of places which, at first, could be considered out-of-place. These are interstitial places, which introduce a language and a textuality that are both in and out. It is to this language and to its necessity that I would now like to turn.

- LANGUAGE IN-PLACE AND OUT-OF-PLACE

Knowledge and understanding are based on experience, which since Kant has been predicated on an encounter between the subject and the object of knowledge. In order to acquire knowledge of an object, the subject must initiate a process of understanding, which is also a movement towards that object. It is in this sense that, according to Kant, knowledge always takes place in the space in-between the subject and the object. ${ }^{13}$ This movement implies a reciprocal shift of place, which in turn determines and opens up a new space or encounter zone in which subject and object confront each other and experience their own presence. Knowledge and experience, in this context, are always characterised by a change of place, and of the spatial coordinates defining the familiar. One could say that in order to know the subject 
and the object one must experience a process of defamiliarisation, or a shock in which the known is momentarily suspended. Knowledge takes place, therefore, in the neutral zone or interstitial place between known and unknown, and familiar and unfamiliar. If this is true, to experience an object, and to know it, means to see it as if for the first time in a context that, while not necessarily new, is different; simultaneously recognisable and yet peculiarly foreign. In The Formation of the Historical World in Human Sciences Wilhelm Dilthey wrote: 'Even empirical consciousness notices that the sensory qualities exhibited in images are dependent upon the standpoint of observation, upon distance, and upon illumination. Physics and psychology show ever more clearly the phenomenality of these sensory qualities. $^{, 14}$ Distance, the place of observation and illumination are quintessential elements determining the perception of images by a subject. Here Dilthey unambiguously states the centrality of place with regard to phenomenal experiences, and he does so by placing the context above the subject and the object of knowledge. Consciousness, the undisputed centre of individuality since Descartes, takes second stage in relation to space. It is no longer enough to claim cogito ergo sum; it is now imperative to place the being of individuality and consciousness within its location, and to question the autonomy and authority of the 'I' according to the context of his/her surroundings. ${ }^{15}$ Much earlier than structuralism and poststructuralism, and some years earlier than Freud, Dilthey challenged the humanist paradigm of knowledge and aesthetic experience by introducing a reconsideration of phenomenology in which consciousness must confront its own dependence on contingent relations, and its nature as a relational and mediated entity always already embedded in a system of exchanges. Already from this preliminary discussion of the relation between knowledge and experience the significance of the liminal space appears in all its relevance. The entrance into an experience that is also meaningful and epistemologically charged demands a perspective shift that can be brought about by a shock. The space in-between, which is opened up by translation and transnational places, is one of the sites in which a new understanding of the subject can take place. This can be achieved when confronted with an environment that is at once familiar and unfamiliar. It is this mixture of the known and the unknown that will propel the subject into the realisation of his or her own gaps and of an identity that far from being 
homogeneous is multifarious and variegated. Being in the Italian Forum is for an Italo-Australian both reassuring and confusing, for an Australian exciting and voyeuristic and for an Italian utterly disorienting. None of the aforementioned subjects will be indifferent or neutral in their response, precisely because the usual and the common, although present, are counterbalanced by the unusual and uncommon.

If we now turn these considerations to the aesthetic experience tout court we can perhaps gain further insights into the relations between processes of formation and creation. A good starting point could be Michael Foucault's short review of Panofsky's books Essais d'iconology and Architecture gothique et Pensée scolaistique (Essays on Iconology and Gothic Architecture and Scholastic Thought) published in Le Nouvel Observateur on 25 October 1967 and now collected in Dits and ecrits: 19541969 (1994) (Essays and Interviews). ${ }^{16}$ Foucault hails the writing of Panofsky as innovative and even revolutionary because it enables us to revisit 'the relation between texts and the visible', and language and image ('l'analyse des rapports entre le discourse et le visible'. ${ }^{17}$ This contrasts with a strand of classical tradition-here Foucault quotes the work of Émile Mâle-where discourse and language are pivotal to the extent that visual art and sculpture are nothing other than poetry in disguise in which language has done away with words in order to speak them more clearly and powerfully, for Panofsky discourse is just one of the many elements of creativity. ${ }^{18}$ Panofsky's argument, claims Foucault, is not so much intent on proposing the autonomy of the visual and plastic arts, as on emphasising the complexity of the relations between the various modes of expression. But, more importantly, what Panofsky does, at least according to Foucault, is to recalibrate the relation between representation and form, where 'representation is neither exterior nor indifferent to form' ('la representation n'est pas extèrieure ni indifférente à la forme'). ${ }^{19}$ The relations that Foucault describes as he illustrates Panofsky's writing point to the relevant laws of textual combinations and the ways in which the various modes of artistic language can interact and mix, but also emphasise the reciprocal relation of systems of signs within the reality of a particular culture. In other words, what started as a review of artistic discourse ends up as a reflection of the creative process and production which, according to Foucault, are inscribed within the specificity of a given culture. A little earlier in his review, Foucault had claimed that 
signs are culturally connotated and meaningful, and that the structures of language provide an order to things ('Nous sommes convaincus, nous savons que tout parle dans une culture: les structures du langage donnent leur forme à l'ordre des choses.' ('We are convinced, we know that everything speaks within one given culture: linguistic structures bequeath their form to the order of things')). ${ }^{20}$

Foucault's statement is very important in the context of this essay, not only because it stresses the symbolic significance of any signs (objects, buildings etc.) regardless of their status, but also because he adds his voice to the centrality of location with regard to textual production. In line with Dilthey, Foucault emphasises that aesthetic production is the result of a complex interrelation between form and image, which in turn are dependent on the uniqueness of a culture, which is also its situatedness. If spatiality is central to Foucault's understanding of artistic production, so is temporality to the extent that the expression of a culture is decisively marked by time and space. Foucault refers to visual culture in order to exemplify his thought, reminding us that 'style' and symbols are the product of 'formally established rules' ('les règles formelles d'un style'). ${ }^{21}$ These rules will help the viewer to decipher whether the representation on a canvas refers to an angel or a man, and to imagination or reality. They will also guide the interpretation of a gesture that expresses a theme and a concept according to a given typology of rules in which a system of values is incarnated. Yet these value systems change from country to country, and their representation will be different in Dürer and in Le Brun, and will change in the passage from the sixteenth to the twentieth century.

The transnational representations of the end of the twentieth and the beginning of the twenty-first century have dramatically changed the aesthetic categories formulated by Foucault by complicating the temporal/spatial equation in which borders, both temporal and spatial, are blurred and confused. Cultural expression becomes porous not only thanks to an increasing exchange and encounter of cultures embodied by artists inhabiting a plurality of traditions, but also by the concomitant temporal interplay between past, present and future in which the memory of a given culture is played against the background of another culture and vice-versa in a continuous cross-pollination of aesthetic values and symbolic representation. The urban landscape of contemporary global and cosmopolitan cities is also marked by this encounter of values and tastes, generating hybrid 
configurations like the Italian Forum in Sydney in which planning, architecture and symbolism are interesting examples of spatial and temporal thresholds.

But let us pause a little longer on the work of Foucault as a way to introduce Freud's articulation of the uncanny. It is essential in this context to focus on the philosophical framework underpinning Foucault's approach to representation and knowledge, which is shared, apart from some notable differences, by several other intellectual figures in the French strand of structuralism and poststructuralism, including Lacan and Deleuze. Foucault's thought is underscored by the need to examine the 'formal conditions which generate the emergence of meaning' ('conditions formelles qui peuvent faire que la signification apparaisse'). ${ }^{22}$ In this context he challenges Husserl's view that meaning is always already present apart from and in autonomy of individuals, who, by this assumption, are inextricably and pre-determinately invested and influenced by meaning. By contrast, Foucault believes that meaning 'does not happen in isolation, it is not "already" there, or if it is "already" there this is the result of a certain number of conditions, which are formal conditions' ('le sens n'apparait pas tout seul, il n'est pas "déjà là", ou plutôt, "il y est déjà", oui, mais sous un certain nombre de conditions qui sont des conditions formelles'). ${ }^{23}$ The task, therefore, is to investigate the formal conditions that give way to meaning. The specificity of Foucault's philosophical project is that it brackets the centrality of consciousness and human individuality as he embarks on this quest. Similar to Deleuze and Lacan, and following Marx, Nietzsche and Freud, Foucault insists on the relational mode of signification, which cannot be based exclusively on human consciousness but must take into consideration moments of interruption and discontinuities (the unconscious), economic and social relations (Marx) and the drastic review of value systems (Nietzsche). It is in this sense that discourse and the primacy of language, understood here as the representational mode par excellence of the conscious mind that controls meaning according to a rational or mimetic rendition of events, is strongly questioned by Foucault. Even when he interrogates language as the vector of sense production, Foucault privileges the work of authors such as Sade, Bataille, Klossowski and Blanchot where language becomes pure desire (Sade) and even thing as such (Blanchot). In the essay 'La pensée du dehors' ('Thinking from the Outside'), ${ }^{24}$ Foucault illustrates his theory of a new relational mode based on the dislocation of subjectivity by focusing, precisely, on the writings 
of Maurice Blanchot. What emerges from this essay is a language that goes outside of its conventional function, and enters a neutral space in which subject and object cohabit in the absence of hierarchies and attempts of possession and coercion of the object of knowledge on the part of a language at the service of an inquiring subject. Language becomes free of the ordering subject and entertains a new rapport with the thing of language, which is thus simultaneously in language and outside language. On this point, it is important to quote a central passage of Foucault's essay: De là, la nécessité de convertir le langage réflexif. Il doit être tourné non pas vers une confirmation intérieure-vers une sorte de certitude centrale d'où il ne pourrait plus être délog-, mais plutôt vers une extrémité où il lui faut toujours se contester: parvenu au bord de lui-même, il ne voit pas surgir la positivité qui le contredit, mais le vide dans lequel il va s'effacer; et vers ce vide il doit aller, en acceptant de se dénouer dans la rumeur, dans l'immédiate négation de ce qu'il dit, dans un silence qui n'est pas l'intimité d'un secret, mais le pur dehors où les mots se déroulent indéfiniment.

It is necessary to reconsider thinking. It must be thought not so much as the expression of interiority-a kind of central certainty from which it cannot be displaced-as the experience of a limit at which it will be continuously questioned. Arrived at the border of its very self, thinking will not emerge from the positivity of dialectic contradiction, but instead from the void in which it erases itself. It must proceed towards this void, accepting in turn its effacement within the rumour, the negative immediacy of what it says, and the silence which is not the secret of an intimacy, but the pure outside in which words unfold indefinitely. ${ }^{25}$

Foucault emphasises the experience of a language that is located in-between the identity of the conscious subject and that of an outside devoid of identity and authenticity. The challenge confronting this language and the subjectivity that inhabits it is to embrace the outside and let the familiar and the known accept and enter the experience of out-of-place, the different and the uncanny.

-SituATING THE UNCANNY 
In his famous essay form 1919, 'The Uncanny', Sigmund Freud embarked on a novel investigation not directly pertinent to the field of psychoanalysis as it was conceived back then. ${ }^{26}$ He wished to study the 'subject of aesthetics', which he understood not only as the theory of beauty but also as the theory of the qualities of feelings. What prompted him to interrogate 'the quality of feelings' was the experience of the uncanny, the unheimlich; an experience associated with fear, dread, and disorientation. The research he conducted on the extant secondary literature on the topic of the uncanny was, by Freud's own admission, minimal ('But I must confess that I have not made a very thorough examination of the literature, especially the foreign literature, relating to this present modest contribution of mine.') ${ }^{27}$ He did however read an essay by Ernst Jentsch written in 1906 on this topic, 'On the Psychology of the Uncanny', in which Jentsch provided a definition of the uncanny as the feeling triggered by an experience of the unfamiliar, and the unusual. By way of explanation Jentsch illustrated the story 'The Sand-Man' by E.T.A. Hoffmann in which a supposed woman, Olympia, turns out to be an automaton. The uncanny is, thus, the uncertainty, and the possibility, of confronting an alien entity whose resemblance with us is strong. However, Freud also drew on a linguistic and etymological analysis of the term 'unheimlich' and its opposite 'heimlich' ('the known', 'the familiar') to find that differences of and separations in meanings are not completely obvious. Certainly they do not point to a clear opposition of two separate entities: the 'I' and the 'Other'. Indeed, Freud was attracted by Schelling's definition of the uncanny, according to which the uncanny is the name for everything that ought to have remained ... secret and hidden but has come to light. ${ }^{28}$ But exactly where is this everything hiding? Freud's hypothesis is that far from the uncanny referring to something new and foreign, unfamiliar and unknown, it is rather the familiar which has been repressed and that resurfaces thanks to particular situations and events. The hiding place in Shelling's definition is, according to Freud, to be found in the very subject experiencing the feeling of the uncanny: '[the] uncanny is in reality nothing new or alien, but something which is familiar and oldestablished in the mind and which has become alienated from it only through the process of repression. ${ }^{29}$ It is no accident that in Freud's view the uncanny is associated with the figure of the double, and involuntary repetitions. According to 
Freud, there is nothing more uncanny than watching ourselves in the mirror without recognising the image that we look at.

The notion of the 'unfamiliarity of the familiar', if I can refer to it as this, is very significant for the overall argument of this essay since what I hope to articulate within the context of transnational textuality and language is the continuous relation and mediation of self and Other played along the axis of aesthetic, social and cultural tensions such as acceptance and rejection, dialogue and conflict, the local and the global. Several of these tensions are generated by the assumption that the 'I' and the 'other' are intractably different and must be kept separated. The very traditional notion of culture is predicated on difference and separation, and the necessitywhich at times becomes a political urgency-to preserve and maintain the specificity of one's own culture as opposed to another culture. ${ }^{30}$ In the global and transnational context this tension finds incredible resonance, which is simultaneously experienced through a feeling of uncanny recognition or rejection. It is this sense that uncanny, here, is not only the feeling of uneasiness, discomfort, fear and anger, but also that of marvel, positive surprise, curiosity and willingness to share. We can speak, therefore, of uncanny surprise and curiosity as the positive impulse to meet the other in us or to recognise in us the traits of the other. The Italian Forum is both a replica and a mirror, and as such fits perfectly the suggestions that triggered Freud's articulation of the uncanny. Like Olympia in Hoffman's tale, the Italian Forum has the ambition to display something other than itself as it stands in the place of an absent original; it is in turn a mirror in which the image reflected therein is partly our own and yet uncannily different. The Italian Forum aspires to replicate the atmosphere of the Italian square; that is, a complex mixture of private and public life, community living, an extended and open living room, a family event, and the constant relation between the present (the quotidian reality of chatter and encounters, business deals and leisure, chance meetings and observation) and the past represented by the symbolic presence of statues, fountains, and buildings which are simultaneously an aesthetic attraction as well as a strong display of power and admonition. This atmosphere is potentially replicable and yet, as we have seen in our discussion of Foucault and Dilthey, social and cultural experience and exchange are invariably informed by the context in which they occur and by the forms that order the language or symbolic meanings of 
representation. The symbolism that characterises the Italian Forum is at once identitarian (the celebration of the Italian Community) and liminal (the celebration of identity in the context of the host country). It is the meeting of two seemingly opposite forces that opens a new space of discourse whose symbols are always already embedded in the concept of the replica and mirror. For instance, the bell tower in the Italian Forum is inherently hybrid, divided as it is between the symbolic presence of the secular and temporal powers, the Church and the State. The statue of Dante, apart from its size, is decentralised and marginal, more like a chance-like presence than a stamp of authority. It is by gazing at these incongruous aspects of alleged national symbolism that the viewer questions her own position and belonging: is this position central or marginal, and is the individual the subject or object of action? It is this suspension that triggers a feeling of disorientation and curiosity that can be mobilised critically to dig deeper into the meanings and significance of the transnational experience. This is why I believe that the uncanny experience enacted by places like the Italian Forum is crucial as a vehicle of analytical reflection on the nature of cultural encounters.

There is, though, another important section in Freud's essay 'The Uncanny' that warrants our attention, especially given our focus on social objects, and urban spaces: texts and language that carry a symbolic significance, and relate to reality through a narrative rich in meanings, and metaphors that are not without analogy to those found in more traditional and conventional texts such as fiction or film. Towards the end of his essay Freud stresses 'we should differentiate between the uncanny that we actually experience and the uncanny that we merely picture or read about ${ }^{31}$ since fiction demands we suspend disbelief, or clearly states that what is represented therein is pure fantasy (Freud makes the examples of fairy tales, but also of fictional texts such as Dante's Comedy, in which the continuous appearance of dead people, souls, demons and angels do not produce the experience of the uncanny in the reader). Freud continues by saying the experience changes, however, should 'the writer pretend to move in the world of common reality'. ${ }^{32}$ Then, expectations and experiences will be subjected to similar reaction of fear and the uncanny as those experienced in reality. Freud is not only emphasising here the important distinction between fiction and reality, imagination and contingency, he is also referring to formal processes of aesthetic production, the forms producing 
meaning that Foucault speaks about and which Freud elects not to engage with in his essay. What is it that happens as a text is produced, and what are the internal logic, desires, and emotions driving it? As Lacan has indicated the thing of art, that which brings about the becoming of the work itself, remains undisclosed not so much because of a metaphysical secrecy or a linguistic inadequacy to say it, but rather as a consequence of an inherent separateness that cannot be subsumed by the work. ${ }^{33}$ This, as Agamben writes in The Coming Community, is the experience of the non-linguistic in language. ${ }^{34}$ It is, in other words, the presence of an extra linguistic thing, which although necessary to the work of art and in a constant relation to it, is always already external to it. ${ }^{35}$ It is this thing that propels the process of creative production and representation and makes art possible by remaining utterly other from art. This void acquires for Lacan ontological and aesthetic significance insofar as the thing is the unsayable that inhabits every act of artistic creation. ${ }^{36}$ It is because of this that in Lacan the thing becomes a strong metaphor for the desire to reconnect with the void of the inevitable loss, be it God or the mother figure. ${ }^{37}$ Artistic production becomes, therefore, a process of sublimation, that has the purpose of constructing fetishes and objects through which to contemplate the thing of art. Of course, this is a false hope insofar as the object is a mere simulacrum of the thing, while the thing itself stays invisible yet present. ${ }^{38}$

To summarise, the objects that acquire meanings through the process of creative production contain, and yet cannot fully express, the origin, the thing, that instantiated the act of creating in the first instance. They are a kind of translation in which the voice of the original echoes in the absence of the voice. It is the desire to reconnect with the thing that drives the artist to produce something in which the thing itself is absent and yet its symbol is crystallised into a meaningful form. The transnational language of urban spaces follows a similar trajectory. The dynamic at work between the original culture (the past) and the adopted culture (the present) generates a complex alphabet of sign-meaning determined by what Husserl would call the active process of memorisation, in which the desire to say is triggered by a memory that comes to react with the experience of the present. ${ }^{39}$ The thing of the creative process, in this instance, is not so much the lost origin of the past as the threshold and encounter between past and present. Paul Carter would call this zone a turbulent zone; a highly charged area of cultural exchange in which rigid 
understandings of authenticity and identity are questioned. ${ }^{40}$ The object of transnational language is, therefore, the symbol given to turbulent encounters and the process of memorisation, whose process of formation is strongly coloured by the methodology of translation described by Benjamin and outlined at the beginning of this essay.

Is this what happens when planning to replicate an Italian square in the middle of an Australian city? One could argue that other interests underpin a project such as the Italian Forum, the primary being commercial interests. This is certainly true, yet it remains that these interests acquire a language and forms which are nonetheless meaningful, speaking of heritage, images and symbolic values that are brought to bear upon another heritage and its images and symbolic values. It is in this sense that the shape and the objects of the Italian Forum in Sydney have a value that transcends their contingency and yet is marked by it. The Italian Forum is simultaneously the thing that stands for an alleged idea of Italy and the sum of the objects assembled together to give form and order to this idea. Therefore, it represents an origin whose thingness is removed and forever external to it. And yet this very thingness reverberates in the objects that allude to it continuously. These objects are copies and simulacra. But what is astonishing in the context of the Italian Forum, is the fact that these objects are openly and unashamedly cheap copies. Their inauthenticity is on display for everybody to see, admire and wonder at. This explicitness is not so much the result of an aborted translation as of the inevitable process of mediation between two cultures, languages and traditions. In other words, the Italian Forum is the result of the transnational language in action, in which symbolic meanings are inherently and quintessentially open and in which the thingness of incomplete objects lingers in-between the lines of exchange and encounter; it is there and yet forever dispersed. It is only now, after this discussion, that the reasons the Italian Forum is the celebration of the Italian-Australian community, and not, certainly, of the Italian identity, Italian culture or the Italian nation, become clear. In contrast to Lacan's simulacra, which strive to fill the gap with the lost thing of desire, the simulacra of transnational spaces celebrate their specificity and separation from the lost thing representing the origin, belonging and authenticity. 
The project to celebrate the achievements of the Italian community in Australia by building an 'Italian square' in Sydney began in the Bicentennial year of 1988 when the New South Wales Government donated a site in the centre of Leichhardt to the Italo-Australian community 'on condition that an Italian piazza and cultural centre be built upon it'. ${ }^{41}$ To mark the importance of this project, on 16 October 1988 the foundation stone of the Italian Forum was unveiled by the then President of the Republic of Italy, Francesco Cossiga. As the documents on the Italian Forum, obtained through CO.AS.IT., state:

The Italian Forum project is the result of community consultation which has been architecturally defined by the internationally renowned Romaldo Giurgola, designer of the new Australian Parliament. The project was conceived to celebrate 40 years of Italian integration in the area and to hold Leichhardt up as a model of social change and cultural revival. For the first time in the history of the Italian community in Australia, people of different ages and beliefs have come together to work on a project bound by a common denominator which fires their imagination and enthusiasm.

The idea of the Italian Forum was driven by a passionate sense of achievement, hard work and the belief in the strong contribution made by Italian-Australians, but also by a sense of cultural sharing, encounter and exchange. In the minds of the promoters the piazza 'expressed the spirit of the community and effected social continuity' but it also revolved around 'the challenge of redeveloping urban spaces into living and liveable neighbourhoods'. The Italian Forum is, then, a tribute to the Italian heritage as it has developed, morphed and adapted in contact with other cultures and traditions. It points to a cherished past and it places this past in direct contact with the present through the idea of 'continuity'. But this project seems to also be aware of the significant cultural and identitarian implications evoked by and through urban planning and design in which imagination and symbolism meet and effect space and time, looking for a fine balance between past, present and future. It is in this sense that the desire to preserve identity-what Lazzarini calls identità resistenziale ('identity of resistance'), the need to form gated community which protect by offering and producing solidarity—gives way to the impetus to 'produce 
identity' (identità progettuale) as in those transnational community who attempt to imagine new forms of cohabitation. ${ }^{42}$

The committee representing the Italian community in Australia intended celebrating the Italian presence by way of a site that would offer a strong and immediate symbolic reminder of what Italian culture, traditions and values are famous for. By choosing the piazza, the committee wished to emphasise the central role the community plays as a social, cultural and economic entity, the continuous relation and synergies between the private and the public, and the willingness to share these values of exchange and dialogue through their spectacularisation achieved by displaying, as in a living theatre, a particular style of life. The piazza as a symbol for Italy is part of an imagined Italy that is the result, as we have seen, of a temporal and spatial dialogue combining time (rural Italy, industrial Italy) and space (Italy and Australia). The space of the now, Australia, interacts and comes into active exchange with mixed time (medieval Italy, renaissance Italy, modern Italy) conjuring up a set of images which are the result of a combination of memories, experiences, knowledge and interests. It is precisely when these images are mobilised to produce symbols-that is textual entities such as literature, architecture and art in general-that the interstitial nature of the transnational experience becomes central to understanding the result of such symbolism. It is clear that the very intention to replicate an Italian square in Sydney is predicated on the impossibility of transferring an actual Italian square in Australia. The Italian Forum had to be built from scratch according to a series of images which in the end offered a symbolic representation of not only Italy, but of Italy in constant relation with Australia. The constant relation between Italy and Australia implies by necessity the interaction between Italians, Australians and Italo-Australians. This is the landscape (Carter would call it a turbulent landscape) of transnational language and textuality. Some of the characteristics of this language are openness, derived from a constant and continue dynamicity; liminality, instantiated by the condition of in-between and translation-the very grammar and structure of the transnational language always already in transit between languages and cultures. As indicated at the beginning of this article, in my essay 'Translation and the Urban Space' I claimed that the attempt to replicate an Italian square in Sydney is the celebration of 'bad translations'. I argued that the paradoxical symbolism enacted in the Italian Forum 
through the minuscule statue of Dante, for instance, or the oxymoronic language of the site where an enclosed amphitheatre stands in the place of a declared square, actually succeeded in reminding the visitor that the original was somewhere else. The 'bad translation' of the Italian Forum alerts us to the fact that we are not in Italy, that we cannot be in Italy, yet it tells us that we are in an interstitial place, the result of the desire to re-enact a complex experience in which the origin is only an element of the equation.

What I failed to notice then, though, is that the Italian Forum is much more than the sum of the original/translation relation, and that its complexity must be measured not so much by way of the traditional framework of translation theory, in which the greater or lesser success of the translation is based on its relation to the original. The forum is rather an example of an interstitial textuality, an open-ended landscape where the symbolic imagination at work results from a process of sedimentation that defies the notion of closure in view of its inevitable dynamicity. It is not, therefore, so much a 'bad translation', as the actual process of translation captured as it enacts moments of encounters and departures among cultures and traditions. In the Italian Forum we find the echo of the Italian history and tradition impersonated by the statue of Dante, for instance, and yet the solemnity of this tradition, which is both a monitor and a celebration, is mediated by the quotidian reality of the migratory experience in which the sense of identity is complicated and enriched by the day-to-day struggle of recognition and acceptance. In comparison to the enormous and often white statues of Dante in Italy-let us think, for example, of the statue of Dante in piazza Santa Croce in Florence ${ }^{43}$ - the Dante of the Forum is black and small, simultaneously a paradox and irony, alluding perhaps also to Italianesque domestic architectural features of the 1960s and 1970s with their miniscule columns and small figures in the front garden or backyard. But apart from the cultural symbolism of the statue, the porticos, the municipal or bell tower, the amphitheatre or square, what resonates more highly in the Italian Forum is the perceived centrality of food and leisure, a trope that is clearly shared by Italians and Australians alike. It is in and around this idea that Australia meets Italy and that Australians enact their impersonations of Italians while in Australia. Food, wine and shopping (for Italian-designed items) represent the crossroads where the desire to display a cultural identity and heritage matches the willingness to share it by 
becoming one with that heritage. It is the moment at which the mirror of otherness can be turned, in fact is willingly turned, upon us. In a word, the Italian Forum is the result of two not always irreconcilable desires, that of celebrating and displaying an ethnic heritage and that of turning ourselves into the Other from the safe distance of impersonation. This interstitial textuality, I would argue, is often enacted for commercial interests, yet it resonates with much more complex and often submerged symbolism which, as I have attempted to demonstrate in this article, may be the first step towards a language and design that can have far reaching implications and significance and lead to the construction of transnational and cosmopolitan communities.

Paolo Bartoloni is Established Professor of Italian Studies at the National University of Ireland, Galway. He has published extensively on continental theory and philosophy, especially the works of Giorgio Agamben, Walter Benjamin, Martin Heidegger, Gianni Vattimo and Mario Perniola, and their impact on the reception of authors such as Blanchot, Calvino, Caproni and Svevo. Bartoloni is the author of On the Cultures of Exile, Translation and Writing (2008) and Interstitial Writing: Calvino, Caproni, Sereni and Svevo (2003) and co-editor of the thematic issue Ambiguity in Culture and Literature (CLCWeb, 2010). See:

<http://www.nuigalway.ie/italian/staff/paolo_bartoloni.html>.

\footnotetext{
-NOTES

1 Paolo Bartoloni, 'Translation and the Urban Space', Literature and Aesthetics, vol. 15, no. 2, December 2005, pp. 109-18.

2 Martin Heidegger, 'Letter on Humanism', in Martin Heidegger: Basic Writings, ed. David Farrell Krell, Routledge, London, 1993, pp. 213-65. This notion is later employed again by Heidegger to articulate his understanding of poetic language. In 'The Nature of Language' he writes: 'The being of anything that is resides in the world. Therefore this statement holds true: Language is the house of Being.' 'The Nature of Language', in Martin Heidegger, On the Way to Language, trans. Peter D. Hertz, Harper, San Francisco, 1971, pp. 57-108 (p. 63).
} 
${ }^{3}$ Reflecting on the meaning of the old word bauen and its derivates, such as Buan, Heidegger writes: 'The way in which you are and I am, the manner in which we humans are on the earth, is Buan, dwelling. To be a human being means to be on the earth as a mortal. It means to dwell.' 'Building Dwelling Thinking', in Martin Heidegger, Poetry, Language, Thought, trans. Albert Hofsadter, Harper and Row, New York, 1971, pp. 145-61 (p. 147).

${ }^{4}$ For a discussion of Benjamin and translation see my On the Cultures of Exile, Translation, and Writing, Purdue University Press, West Lafayette, 2008, especially pp. 9-41.

5 To my knowledge to date there is only one critical study that looks at the philosophy of Heidegger by applying the framework of translation; I refer to Gino Giometti, Martin Heidegger: Filosofia della traduzione, Quadlibet, Macerata, 1995.

6 This is especially evident in Martin Heidegger and Eugen Fink, Heraclitus Seminar, trans. Charles H. Seibert, Northwestern University Press, Evanston, 1993.

7 For an introduction to Heidegger and Greek thought see Heidegger and the Greeks, eds A. Hyland and J. P. Manoussakis, Indiana University Press, Bloomington and Indianapolis, 2006. See also Martin Heidegger's diary about his first and only journey to Greece, Sojourns: The Journey to Greece, State University of New York Press, New York, 2005.

8 For a discussion of Heidegger and place see also Jeff Malpas, Heidegger's Topology: Being, Place, World, The MIT Press, Cambridge, MA, 2006.

${ }_{9}^{9}$ Anna Lazzarini, Polis in fabula. Metamorfosi della città contemporanea, Sellerio, Palermo, 2011.

10 The theorist of place Paul Carter defines urban planning as 'a continuum of exfoliation that is unified by the idea that places come into being mythopoetically, that is, through enactments of the imagination'. From a paper, 'Turbulent Zones: the poetics of sustaining places in unsustainable times', delivered at the National University of Ireland, Galway, 12 April 2012. The paper is available at <http://www.materialthinking.com.au/2012/04/turbulent-zones/>.

11 Tonino Griffero, Atmosferologia. Estetica degli spazi emozionali, Laterza, Bari, 2010, p. 16.

12 Griffero, p. 30.

${ }^{13}$ See Immanuel Kant, Critique of Pure Reason, trans. Paul Guyer and Allen W. Wood, Cambridge, Cambridge University Press, 1999; and especially p. 155: 'In whatever way and through whatever means a cognition may relate to objects, that through which it relates immediately to them, and at which all thought as a means is directed as an end, is intuition. This, however, takes place only insofar as the object is given to us; but this in turn, is possible only if it affects the mind in a certain way.' (My italics). 14 Wilhelm Dilthey, The Formation of the Historical World in Human Sciences, Princeton, Princeton University Press, 2002, p. 111. Also available on line at <http://www.humanitiesbook.org/>. 15 Paul Carter argues something similar when, quoting de Certeau, he emphasises 'stories bear within them ghostly reminders of our quotidian journeying to and fro in our constructed environments' and 'convey in words a sense of the body-subject occupying, inhabiting, and moving through space, thus transforming it into places imbued with particular meaning and specific presence.' 'Turbulent Zones'. 
16 Michel Foucault, 'Les mots et les images', in Dits et écrits, 1954-1988, eds Daniel Defert and François Ewald, Éditions Gallimard, Paris, 1994, pp. 620-3.

17 Foucault, 'Les mots et les images', p. 621. My translation.

18 Ibid., p. 621.

19 Ibid., p. 623. My translation.

20 Ibid., p. 621. My translation.

21 Ibid., p. 622. My translation.

22 Michel Foucault, 'Qui êtes-vous, professeur Foucault', in Dits et écrits, 1954-1988, pp. 601-20 (p.

602). My translation.

23 Ibid. p. 602. My translation.

24 Michel Foucault, 'La pensée du dehors', in Dits et écrits, 1954-1988, pp. 518-39

25 Ibid., p. 532. My translation.

26 Sigmund Freud, 'The Uncanny', in Complete Works, ed. Ivan Smith (ed), 2010,

$<$ www.valas.fr/IMG/pdf/Freud_Complete_Works.pdf>.

27 Ibid., p. 3675.

28 Ibid., p. 3678.

29 Ibid., p. 3691

${ }^{30}$ For a general discussion of culture, nation, and identity see Seyla Benhabib, The Claims of Culture: Equality and Diversity in the Global Era, Princeton, Princeton University Press, 2002. Especially significant in the context of this essay is Benhabib's claim that: 'Cultures themselves, as well as societies, are not holistic but polyvocal, multilayered, decentered, and fractured systems of action and signification.' (26).

31 Freud, p. 3698.

32 Ibid., p. 3699.

33 See for instance Jacques Lacan, Le Séminaire VII, L'éthique de la psychoanalyse, Seuil, Paris, 1986 (The Ethics of Psychoanalysis, trans. Dennis Porter, Routledge, London, 1992).

34 'The being-in-language of the non-linguistic' ('L'essere-nel-linguaggio-del-non-linguistico'). Giorgio Agamben, The Coming Community, trans. Michael Hardt, University of Minneapolis Press, Minneapolis, 1993, p. 103.

$35^{\prime}$...ce que nous décrivons comme ce lieu central, cette extériorité intime, cette extimité, qui est la Chose', Lacan, Le Séminaire, p. 167; ('what we described as the central place, as the intimate exteriority or 'extimacy', that is the Thing' Lacan, The Ethics, p. 139).

36 'La création de la poésie consiste à poser, selon le mode de la sublimation propre à l'arte, un object que j'appellerai affolant, un partenaire inhumain.' Lacan, Le Séminaire, p. 180; ('By means of a form of sublimation specific to art, poetic creation consists in positing an object I can only describe as terrifying, an inhuman partner.' Lacan, The Ethics, p. 150). 
37 '...le Souverain Bien, qui est das Ding, qui est la mère, l'objet de l'inceste, est un bien interdit, et qu'il n'y a pas d'autre bien.' Lacan, Le Séminaire, p. 85; ('the Sovereign Good, which is das Ding, which is the mother, is also the object of incest, is a forbidden good, and that there is no other good.' Lacan, The Ethics, p. 70).

38 'La question de das Ding reste aujourd'hui suspendu à ce qu'il y a d'ouvert, de manquant, de béant, au centre de notre désir.' Lacan, Le Séminaire, p. 102; ('The question of das Ding is still attached to whatever is open, lacking or gaping at the center of our desire.' Lacan, The Ethics, p. 84).

${ }^{39}$ In The Origin of Geometry Husserl writes: 'the active recollection of what is past [involves] an activity of concurrent actual production.' Edmund Husserl, 'The Origin of Geometry', in The Crisis of European Sciences and Transcendental Phenomenology, trans. David Carr, Evanston: Northwestern University Press, 1970, pp. 353-78 (p. 370).

40 'Turbulence is the name of the environmental unconscious, that self-organising manifold of perturbations, pressures, bubbling noises, interruptions in the flow that recall us to the contingency of our human condition, its dependence on environmental factors.' Paul Carter, 'Turbulent Zones'.

41 Documents outlining the history of the Italian Forum in Sydney, CO.AS.IT., Casa d'Italia, 67 Norton Street, Leichhardt, NSW 2040. Italics in the text. All subsequent quotations are from the same source. 42 See Lazzarini, p. 149.

43 On the statue of Dante and its symbolism in Piazza Santa Croce in Florence see also the essay by Anne O'Connor, 'Dante Alighieri-from Absence to Stony Presence: Building Memories in NineteenthCentury Florence', Italian Studies, vol. 67, no. 3, November 2012, pp. 307-35. 